Available Online : https://proceeding.researchsynergypress.com/index.php/cset/index

RSF Conference Series: Engineering and Technology

ISSN 2809-6843 (Online) | 2809-6878 (Print)

Volume 1 Number 1 (2021): 426-431

\title{
Supporting Capacity of Tourism Areas in Ngandong Beach, Sidoharjo Village, TepusDistrict, Gunungkidul Regency, D.I.Yogyakarta
}

\author{
Johan Danu Prasetya', Dian Hudawan Santoso², Ira Andriani Roting ${ }^{3}$ \\ 1,2,3 Department of Environmental Engineering, Faculty of Mineral Technology, Universitas Pembangunan \\ Nasional Veteran Yogyakarta, Indonesia;
}

\begin{abstract}
The Special Region of Yogyakarta is an area that is used as a recreational destination and is visited by many tourists.Many tourism activities are supported by the various facilities that have been provided by the community, government, entrepreneurs, and local governments. Tourists who came to Gunungkidul Regency with a combined number of foreign tourists and Nusantara tourists reached 3,661,612 tourists in 2019. High waves on July 252018 damaged tourist attractions and also settlements on Ngandong Beach. The purpose of this study is to determine the carrying capacity of the tourism area on Ngandong Beach. The area's carrying capacity is known by calculating the number of visitors who come to Ngndong Beach and calculating using the formula for regional carrying capacity. Based on the calculation results, the carrying capacity of the area on Ngandong Beach can accommodate 1,225 people/day and hasan area of $26,661 \mathrm{~m}^{2}$. The results obtained will be suggestions for the government and the surrounding community in processing the coastal areas on Ngandong Beach.
\end{abstract}

Keywords: Regional Carrying Capacity; Ngandong Beach, Tourism.

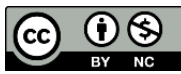

This is an open access article under the CC-BY-NC license

\section{INTRODUCTION}

Beach tourism has several categories in tourism activities, one of which is beach recreation tourism. Recreation is an activity carried out to recover physical and mental conditions after experiencing fatigue at work. Beach recreation aims to relieve fatigue and seek satisfaction by relaxing on the beach. Carrying capacity is the use of resources before they are degraded and there is no negative impact on the resources so that it does not reduce satisfaction for visitors and there is no harm to the community and local culture. The development of the tourism concept is characterized by the existence of restrictions for tourists who come to visit. If a tourist activity does not limit the number of visitors, then it will damage and threaten the sustainability of the existing resources in that location.

The Special Region of Yogyakarta is famous as an area that has many tourist attractions, one of which is beach tourism. Ngandong Beach is included in the ranks of the southern coast and is included in the Baron and Pok Tunggal Beach areas which are located in Sidoharjo Village, Tepus District, Gunungkidul Regency, Special Region of Yogyakarta. Based on data from the Special Region of Yogyakarta Tourism Office in 2019, it was stated that foreign tourist visitors who came to the Special Region of Yogyakarta were 551,547 people and for Nusantara tourists who visited as many as $27,772,847$ people, so that the total visitors who came to the Special Region of Yogyakarta reached 28,324,394 people. Tourists who came to Gunungkidul Regency in 2019 reached 3,661,612 people.

Ngandong Beach is one of the beaches that has a beautiful natural panorama and is interesting to visit. This study has the aim of analyzing the carrying capacity of the area in accommodating visitors who are on Ngandong Beach.

Corresponding author:

johan.danu@upnyk.ac.id, dian.hudawan@upnyk.ac.id, iraandriani6@gmail.com

DOI: $10.31098 /$ cset.v1i1.415

Research Synergy Foundation 


\section{LITERATURE REVIEW}

According to Marfai et al (2011) coastal areas are very dynamic areas with various kinds of physical processes including sea level rise, land subsidence, and erosion-sedimentation. All the processes that occur affect shoreline changes and also the development of coastal landscape forms. The potential of coastal areas that can contribute to the country's economy but has not been managed properly, such as the function of coastal and oceanic areas as a place for recreation and tourism, transportation and communication media, energy sources, educational facilities, and research (Trinanda, 2017).

The carrying capacity of the area is the maximum number of visitors that can be accommodated by an area that has been provided and does not cause disturbance to humans and nature (Yulianda, 2007 in Johan, 2011). The carrying capacity of a tourist area can be influenced by the number of tourists who come to visit a tourism place and the ongoing tourism activities can cause direct and indirect effects on the environment (Arlius, 2017). According to Simon et. Al (2004) in Bibin (2017) argues that carrying capacity is the maximum use of carrying capacity before degradation occurs and does not result in negative influences that occur in resources and does not reduce visitor satisfaction or harm the economy of the community and local culture.

Tourism carrying capacity is used to overcome and also limit the number of certain tourism developments in order to maintain local communities, cultures and the environment and is a recreational capacity so that case formulation and also actions for management that can cause the effects that occur are getting smaller (Mc Cool \& Lime, 2001 in Bibin, 2017). Limiting the number of tourists is a characteristic based on the development of the concept of tourism, where if the number of tourists arriving is not limited it will disrupt the sustainability of these resources (Pickering \& Hill, 2007 in Bibin, 2017). The value of carrying capacity as a limit that can be used in development as a benchmark for appropriate use of space using the maximum level (Silva et.al, 2007 in Muflih, 2015). The number of tourists who come because of this can be limited as a result can reduce the effect of the damage that occurs. The visitor approach can be done by providing knowledge about protection so that it can be used as marketing for tourism activities and nature-based experiences that have potential (Ballantyne et al, 2009 in Muflih, 2015).

The value of the carrying capacity of the area will be used as the basis for decisions in choosing the direction of tourism development in the area. The carrying capacity of the tourist area is used as a benchmark for the maximum number of visitors that can be accommodated by the facilities and infrastructure of the tourist attraction. If the capacity of the object's infrastructure is exceeded, negative effects will appear, for example, declining resources, harming the people economically and culturally and breaking down the sense of satisfaction of visitors when traveling (Simon et. al, 2004 in Muflih, 2015). The direct impact of marine and coastal tourism can be in the form of a decrease in the quality of natural resources, pollution, loss of native places and threatened wildlife. Non-exclusive impacts can arise due to the existence of supporting infrastructure, waste disposal by tourism service providers and population growth (Gladstone et. al, 2013 in Muflih, 2015). According to Clark, 1995 in Muflih, 2015 said that improvement considerations need to pay attention to aspects such as physical, biological, social and psychological environmental requirements in supporting tourist activities without reducing environmental quality and also tourist satisfaction on traveling. Management of coastal tourism, beaches and tourism development can be integrated as a result can improve the quality of the environment periodically (Jennings, 2004 in Muflih, 2015)

According to Cisneros et. al. (2016) in Rahima (2020) the carrying capacity of the area can affect the psychological carrying capacity of tourists, which can be interpreted if the number of tourists arriving to visit exceeds the carrying capacity of the place, the satisfaction of tourists arriving to visit will decrease.

Tourists who visit tourist attractions have a specific purpose, including resting/walking leisurely, camping, studying/observing/researching or a combination of several activities. Various activities carried out by tourists are expected to provide entertainment and recreation (Umar, 2013). 


\section{Supporting Capacity of Tourism Areas in Ngandong Beach, Sidoharjo Village, Tepus District,} Gunungkidul Regency, D. I. Yogyakarta

Johan Danu Prasetya, Dian Hudawan Santoso, Ira Andriani Roting

\section{METHODS}

The method in this research is divided into two stages, namely; methods of data collection and analysis methods. Data collection methods will be further divided into two types; primary data and secondary data. Primary data in the form of direct observations in the field and interviews. Secondary data is in the form of data from related agencies such as rainfall data.

The method used in this research is in the form of a direct survey, measurement, mapping, interview, and data analysis. The data obtained will be analyzed to achieve the objectives of this study.

\section{Carrying Capacity of Region}

Carrying Region According Yulianda (2007) in (Nugraha, et al., 2013) using the formula: Description:

DDK = Capability Areas (per meter)

$\mathrm{K}=$ Potential ecological visitors per unit area $\left(\right.$ per $\left.^{2}\right)$

$\mathrm{Lp} \quad=$ Total area over the length of the area that can be utilized $\left(\mathrm{m}^{2}\right)$

Lt $\quad=$ Unit area for certain categories $\left(\mathrm{m}^{2}\right)$

$\mathrm{Wt}=$ Time provided by the area for tourism activities in one day (hours)

Table 1 Ecological Potential of Visitors and Area of Activity

\begin{tabular}{|c|c|c|c|}
\hline $\begin{array}{c}\text { Type of } \\
\text { Activity }\end{array}$ & $\begin{array}{c}\text { K } \\
\text { Visitors) }\end{array}$ & $\begin{array}{c}\text { Unit } \\
\text { Area } \\
\text { (Lt) }\end{array}$ & Remarks \\
\hline $\begin{array}{c}\text { Beach } \\
\text { Recreation }\end{array}$ & 1 & $50 \mathrm{~m}$ & $\begin{array}{c}1 \text { person every } 50 \mathrm{~m} \text { Beach } \\
\text { length }\end{array}$ \\
\hline Sports tourism & 1 & $50 \mathrm{~m}$ & $\begin{array}{c}1 \text { person every } 50 \mathrm{~m} \text { Beach } \\
\text { length }\end{array}$ \\
\hline Swimming & 1 & $50 \mathrm{~m}$ & $\begin{array}{c}1 \text { person every } 50 \mathrm{~m} \text { Beach } \\
\text { length }\end{array}$ \\
\hline Sunbathing & 1 & $50 \mathrm{~m}$ & $\begin{array}{c}1 \text { person per } 50 \mathrm{~m} \text { Beach } \\
\text { length }\end{array}$ \\
\hline Fishing & 1 & $50 \mathrm{~m}$ & $\begin{array}{c}1 \text { person every } 10 \mathrm{~m} \text { beach } \\
\text { length }\end{array}$ \\
\hline Camping area & 5 & $50 \mathrm{~m}$ & $\begin{array}{c}1 \text { person per } 100 \mathrm{~m} 2 \text { beach } \\
\text { length }\end{array}$ \\
\hline
\end{tabular}

Source: Yulianda (2007) in Nugraha (2013)

Tourist activity time (Wp) is calculated with the length of time tourists do in tourism activities. Tourist time is calculated by considering the time that has been provided for the area (Wt). Regional time is the length of time the area begins to open in one day and the average working time is around 10 hours. Prediction of the time required for each tourism activity can be seen in Table 2 .

Table 2 Predicted time required for each tourism activity

\begin{tabular}{|c|c|c|c|}
\hline No & Activity & $\begin{array}{c}\text { Time required } \\
\text { Wp - (hours) }\end{array}$ & $\begin{array}{c}\text { Total Time 1 day } \\
\text { Wt - (hours) }\end{array}$ \\
\hline 1. & Beach Recreation & 6 & 4 \\
\hline 2. & Travelport & 2 & 4 \\
\hline
\end{tabular}


RSF Conference Series: Engineering and Technology

Vol. 1 (1), 426-431

Supporting Capacity of Tourism Areas in Ngandong Beach, Sidoharjo Village, Tepus District, Gunungkidul Regency, D. I. Yogyakarta

Johan Danu Prasetya, Dian Hudawan Santoso, Ira Andriani Roting

\begin{tabular}{|c|c|c|c|}
\hline 3. & Swim & 2 & 8 \\
\hline 4. & Soak & 2 & 5 \\
\hline 5. & Fishing & 2 & 4 \\
\hline 6. & Camping area & 24 & 24 \\
\hline \multicolumn{4}{|c|}{ Source: Yulianda (2007) in Umar (2013) }
\end{tabular}

The results of the calculation of the carrying capacity of the area have units, namely people per meter and the results obtained are the maximum results that can be accommodated inthe area.

\section{RESULTS AND DISCUSSION}

The area's carrying capacity is calculated by knowing the area required for 1 visitor to carry out various activities such as walking, sunbathing, and others. Every 1 visitor according to Yulianda (2007) in (Wunani, Deysandi, 2013) requires 50 meters of beach length. The time required for visitors to carry out activities (wp) is calculated based on the length of time visitors spend traveling at that location. Visitor time is calculated with the time allotted for the area (wt). Regional time is the length of time the area is opened in one day and the average working time is about 8 hours and interviews are conducted to strengthen the data to be taken.

Based on the table of the number of visitors who come to Ngandong Beach, it is stated that visitors who come on weekdays or weekdays will be less than the mountains who come on holidays. Visitors who come on holiday have a purpose to fill the weekend and travel. Data on thenumber of visitors who come to Ngandong Beach within one month can be seen in Table 3.

Table 3 Number of Visitors to Ngandong Beach in One Month

\begin{tabular}{|c|c|c|c|c|c|}
\hline No. & Day/Ladder/Month/Year & Number of Visitors & No. & Day/Stair/Month/Year & Number of Visitors \\
\hline 1. & Monday/8/3/2021 & 406 & 11. & Saturday 27/3/2021 & 958 \\
\hline 2. & Tuesday/9/3/2021 & 397 & 12. & Sunday 28/3/2021 & 1,216 \\
\hline 3. & Saturday /3/3/2021 & 908 & 13. & Wednesday 31/3/2021 & 428 \\
\hline 4. & Sunday/14/3/2021 & 1165 & 14. & Thursday /021 & 489 \\
\hline 5. & Wednesday/17/3/2021 & 417 & 15. & Saturday /2021 & 994 \\
\hline 6. & Thursday/18/3/2021 & 483 & 16 & Sunday 4/4/2021 & 1195 \\
\hline 7. & Saturday/20/3/2021 & 829 & 17. & Monday 5/4/2021 & 438 \\
\hline 8. & Sunday/21/3/2021 & 1204 & 18. & Tuesday 6/4/2021 & 443 \\
\hline 9. & Monday/ 22/3/2021 & 415 & 19. & Saturday 10/4/2021 & 983 \\
\hline 10. & Tuesday/23/3/2021 & 406 & 20. & Sunday 11/4/021 & 1278 \\
\hline
\end{tabular}

(Source: Personal Data, 2021) 


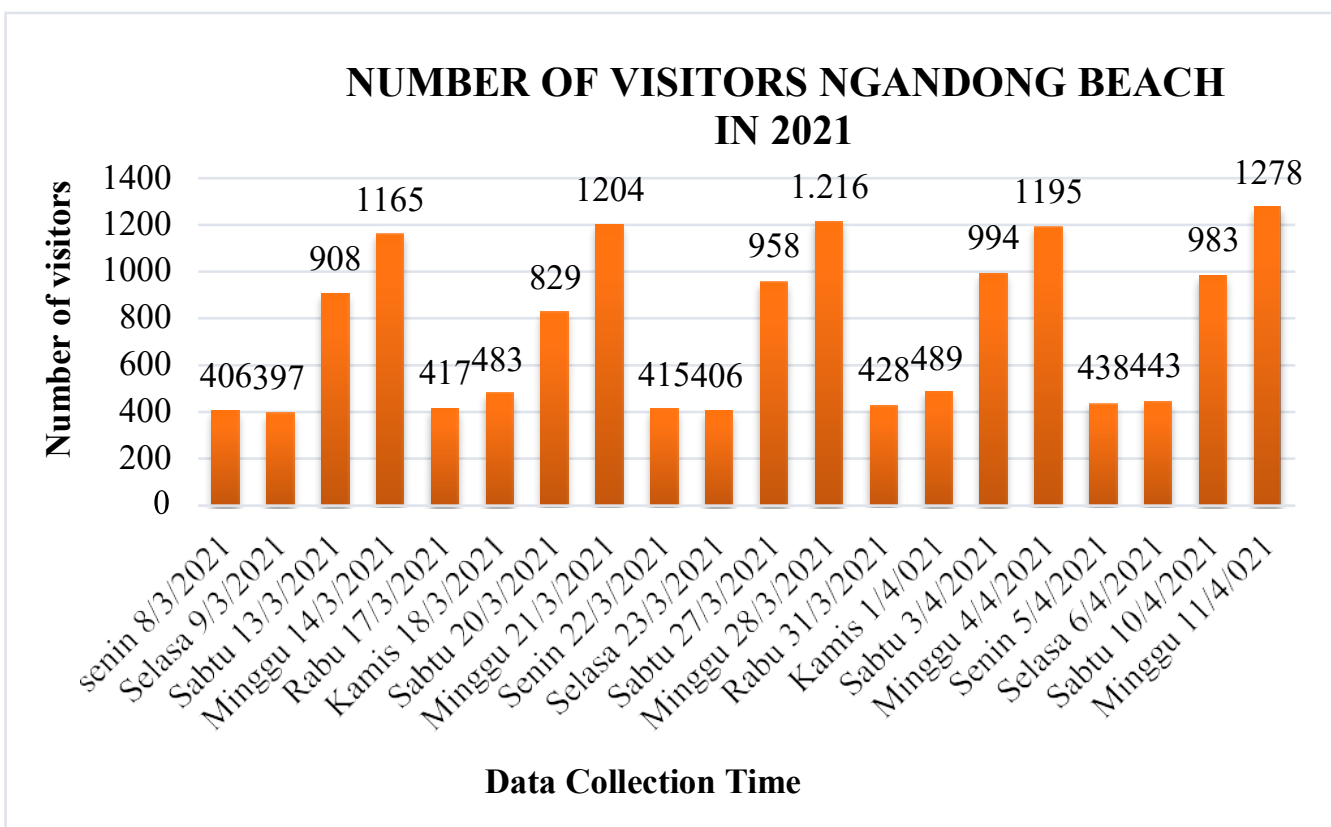

Figure 1 Number of Visitors to Ngandong Beach in Time One Month (Source: Personal Data, 2021)

Measurement of the carrying capacity of the area with the category of beach recreation referring to the formula set by Yulianda (2007) in Wuani, Deysandi (2013) there are some judgments as of the area $\left(\mathrm{m}^{2}\right)_{\text {or }}$ the length of the area that is used (Lp), the unit area for a specific category (Lt), the time provided by the region for tourism activities in one day (Wt), and the time spent by visitors for each particular activity (Wp). Based on these criteria, the results of themeasurement of the carrying capacity of the area asin Table 4 are shown as follows:

Table 4 Results of the Measurement of Regional Carrying Capacity for the Recreation Category

\begin{tabular}{|c|c|}
\hline Parameter & Result \\
\hline $\mathrm{K}$ & 1 \\
\hline $\mathrm{Lp}$ & $26.261 \mathrm{~m}^{2}$ \\
\hline $\mathrm{Lt}$ & $50 \mathrm{~m}^{2}$ \\
\hline $\mathrm{Wt}$ & $7 \mathrm{Jam}$ \\
\hline $\mathrm{Wp}$ & $3 \mathrm{Jam}$ \\
\hline
\end{tabular}

(Source: Analysis Data, 2021)

Data on visitors who come to Ngandong Beach for recreation are then entered into theformula the calculation of the area's carrying capacity is as follows:

DDK $=1$ Person/day $x$
DDK $=1.225$ Person/day




\section{RSF Conference Series: Engineering and Technology}

Vol. 1 (1), 426-431

\section{Supporting Capacity of Tourism Areas in Ngandong Beach, Sidoharjo Village, Tepus District, Gunungkidul Regency, D. I. Yogyakarta \\ Johan Danu Prasetya, Dian Hudawan Santoso, Ira Andriani Roting}

The calculation of the carrying capacity of the area is considered very important to find out the maximum number of visitors that can be accommodated in 1 day to carry out tourism activities, so as not to cause disturbance to both humans and the environment due to the excessive number of visitors. The region's carrying capacity to travel on Turkish recreation Ngandong can accommodate as many as 1,225 visitors/day with an area of $26261 \mathrm{~m}^{2}$ and a length of about 165 meters Ngandong Beach. Each visitor who engages in recreational tourism activities requires about 3 hours to carry out various recreational activities from the total time provided about 7 hours from opening time. The average obtained in the 1month calculation of the number of visitors is 753 people and there is one day, Sunday, April 11, 2021, visitors who come reach 1,278 while the calculation results obtained are 1,225 people/day but the increase in the number of visitors is not too significant. Based on data obtained from guard posts to Drini Beach, Krakal Beach, Sili Beach, Sandranan Beach, Ngandong Beach, Sundak Beach, and Indrayanti Beach, the number of visitors who come is around 500-600 people/day. Visitors who come if they exceed the carrying capacityof the area will disturb and can cause damage to the ecosystem in thearea.

\section{CONCLUSION}

Based on the research that has been done, the results of the analysis of the carrying capacity ofthe area on Ngandong Beach have a carrying capacity of 1,225 people. / day with an area of $26261 \mathrm{~m}^{2}$ and a length of about 165 meters Ngandong Beach.

\section{Acknowledgments}

The authors acknowledge the support of Lembaga Penelitian dan Pengabdian Masyarakat (LPPM) Universitas Pembangunan Nasional Veteran Yogyakarta.

\section{REFERENCES}

Akliyah, L., \& Umar, M. (2013). Analisis Daya Dukung Kawasan Wisata Pantai SebanjarKabupaten Alor Dalam Mendukung Pariwisata Yang Berkelanjutan. Jurnal Perencanaan Wilayah Dan Kota, 13(2), 124600. https://doi.org/10.29313/jpwk.v13i2.1388

Arrow, K., Bolin, B., Costanza, R., Dasgupta, P., Folke, C., Holling, C. S., ... \& Pimentel, D. (1995). Economic growth, carrying capacity, and the environment. Ecological economics, 15(2), 91-95.

Bibin, Muhammad, Yon Vitner dan Zulhamzah Imran. 2017. Analisis Kesesuaian dan Daya Dukung Wisata Kawasan Pantai Labombo Kota Palopo. Jurnal Pariwisata, Vol IV No. 2

Dinas Pariwisata Provinsi DIY, 2019. (2019). Statistik Kepariwisataan Yogyakarta 2019. Analisis Pendapatan Dan Tingkat Kesejahteraan Rumah Tangga Petani, 53(9), 1689-1699.

Nugraha, H. P., Indarjo, A., \& Helmi, M. (2013). Studi Kesesuaian Dan Daya Dukung Kawasan Untuk Rekreasi Pantai Di Pantai Panjang Kota Bengkulu. Diponegoro Journal of Marine Research, 2(2), 130-139. https://doi.org/10.14710/jmr.v2i2.2474

O'Reilly, A. M. (1986). Tourism carrying capacity: concept and issues. Tourism management, 7(4), 254258.

Prasetya, J. D., Hudawan, D., \& Farhaini, N. (2021). Kajian Kondisi Tutupan Karang Terhadap Daya Dukung Wisata Bahari Di Kepulauan Karimunjawa, Jawa Tengah. Jurnal Mineral, Energi, dan Lingkungan, 4(2), 71-77.

Santoso, D. H. (2015). Kajian Daya Dukung Air di Pulau Bintan, Provinsi Kepulauan Riau. Jurnal Sains \& Teknologi Lingkungan, 7(1), 01-17.

Santoso, D., Prasetya, J., \& Saputra, D. (2020). Analisis daya dukung lingkungan hidup berbasis jasa ekosistem penyediaan air bersih di Pulau Karimunjawa. Jurnal Ilmu Lingkungan, 18(2), 290-296.

Wunani, Deysandi, S. N. dan F. K. (2013). Kesesuaian Lahan dan Daya Dukung Kawasan Wisata Pantai Botutonuo, Kecamatan Kabila Bone, Kabupaten Bone Bolango. 1(September), 89-94. http://ejurnal.ung.ac.id/index.php/nike/article/view/1226 